\title{
COMMON HUMAN PATHOGENS; ANTIMICROBIAL ROLE OF GINGER (ZINGIBER OFFICINALE) drfaraz@yahoo.com
}

1. Associate Prof. of Pathology (Bahria University Medical and Dental College)

2. Lecturer

(Bahria University Medical and Dental College)

3. Senior Registrar Medicine FCPS (Liaquat National Hospital)

Correspondence Address: Dr. Naveed Faraz Associate Professor Department of Pathology Bahria University Medical and Dental College, Karachi drfaraz@yahoo.com

Article received on: $11 / 05 / 2016$ Accepted for publication: 29/09/2016

Received after proof reading: 00/00/2016

\section{Dr. Naveed Faraz', Dr. Shaista Khurram², Dr. Sehrish ${ }^{3}$}

\begin{abstract}
Background: Due to easy availability or excess to antibiotics people usually start antibiotic without consulting doctors when they are suffering from illness and as they were feeling well they discontinue the treatment and as a result these bacteria become resistant to those antibiotics which are inadequately used. Also most of the antibiotic have side effect that also produce undesirable effect so after considering all of these issues we want to explore natural compounds for their antimicrobial activity as these compounds have no side effect and cost effective as well. Objectives: We analyzed the antimicrobial activity of ginger (ZINGIBER OFFICINALE) against common human pathogens. Study design: Experimental study. Place and duration of study: All clinical isolates were identified at BUMDC (Bahria University Medical and Dental College) Microbiology Lab (Karachi) by standard biochemical methods. Study conducted between april2015-nov 2015. Material \& Methods: Staphylococcus aureus, Pseudomonas, Vibrio cholera and E.Coli culture sample were taken and again characterized using conventional biochemical, cultural and molecular methods. Then I checked the antimicrobial activity of ginger alone and with soyaoil against these isolates using disc diffusion method. Result: It shows that ginger alone having good antimicrobial activity against pseudomonas but when using after mixing with soya oil its antimicrobial activity decreased as it was note when individually used. Conclusion: Ginger when using alone having good antimicrobial activity then when using in combination with soya.
\end{abstract}

Key words: Antibacterial Activity, Zingiberofficinale, soya oil Staphylococcus aureus, Pseudomonas, Vibrio cholera, E.Coli.

\section{Article Citation: Faraz N, Khurram S, Sehrish. Common human pathogens; antimicrobial role of ginger (Zingiber Officinale). Professional Med J 2016;23(12):1593-1597. DOI: $10.17957 / T P M J / 16.3411$}

\section{INTRODUCTION}

Ginger Zingier officinale is a medicinal plant that has been widely used all over the world. In Islam, herbs and its constituents have important value in diet as well as used for the treatment of various diseases. In ancient time, whenever, allopathic medicines were not actively introduced some herbs or natural plants used to treat different diseases. Nowadays, the increased and inadequate use of antibiotics has induced microorganisms to acquire resistance against these commonly used antibiotics. Also due to increasing prices of antibiotics made them unaffordable for a common person. As a result, we are compelled to use plant origin drugs which are easily available, cost-effective and have considerably minimal side effects. ${ }^{1,2}$
Ginger belongs to ZINGIBERACEAE family. It has strong aromatic, digestive and medicinal properties. It can be used as antimicrobial and antibiofilm agent because of its constituents like gingerol and paradol, shogaols and zingerone. . $^{3,4}$ It vary in its antimicrobial activity in different environmental conditions and so many factors like temperature, $\mathrm{P}_{\mathrm{H}}$ etc would affect its antimicrobial activity. ${ }^{5,6,7}$

The antimicrobial activity is due to specific phytochemicals or essential oils. It inhibits the growth of $E$ coli, proteus, staphylococcus, salmonella, pseudomonas, vibrio cholera and so many other organisms.

Zingerone, an active compound found in ginger, can accumulate the toxins and thus it can prevent 
bacterial diarrhea. E coli members of bacteria referred to as enterobactericea which are gram negative rod shaped bacteria. Pathogenic strains of E.coli can cause gastroenteritis, urinary tract infections and neonatal meningitis. ${ }^{8}$ Ginger has capability to eliminate harmful bacteria such as $\mathrm{E}$ coli, responsible for most the diarrhea, especially in children.

Vibrio cholera is responsible for cholera. Ginger consists of 6 gingerol that binds to cholera toxin, hindering its interaction with the GM1 receptor on intestinal epithelial cells as a result its toxin become ineffective.

Pseudomonas aeruginosa is Gram-negative and opportunistic organism. Pseudomonas aeruginosa produces several virulence factors, responsible for its remarkable ability to form biofilms that renders antibiotic treatment inefficient. The Biofilms of both $P$ aeruginosa and staphylococcus adhere to any surface, living or nonliving and thus it can involve any part of body and as a result it provide protection to so many pathogenic microorganisms. Furthermore, adaptive and genetic changes make them resistant against conventional antibiotic against these organism. Ginger's also have ability to inhibit Pseudomonas aeruginosa and staphylococcus ability to form biofilm..$^{9,10,11}$

\section{METHODS AND MATERIALS}

Study materials Soybean oils and ginger (Zingiberofficinale) were purchased from the local markets. For evaluating antibacterial efficacy of ginger we tested ginger extract against Escherichia coli, Pseudomonas aeruginosa, Staphylococcus aureus, and Vibrio cholera individually and in combination of soya oil as well. All of these bacterial species were isolated and characterized using conventional biochemical tests.

\section{Inoculum preparation}

Triptone soya broth were taken and Escherichia coli, Pseudomonas aeruginosa, Staphylococcus aureus, Vibrio cholera was inoculated in this medium and organism were incubated at $37^{\circ} \mathrm{C}$ for 6 hour. Match the turbidity of this inoculum with $0.5 \mathrm{MacFerland}$ standard. Then this prepared inoculum was used to make a lawn of specific organism over the Mueller Hinton Agar for checking antimicrobial activity.

\section{Preparation of ginger extracts in soybean oil} 10 grams of ginger powder was mixed with $40 \mathrm{ml}$ soybean oil. This mixture boiled for 30 minutes, cooled and filtered through filter paper and collected in a sterile container for use. Extracts was kept at freezing temperature to preserve the antibacterial activity of that compound.

\section{Antibacterial assay}

Filter paper discs (6mm diameter) were prepared, sterilized and store at freezing temperature for further use. A lawn of each bacterial isolate was prepared on MHA plates. Filter paper discs were placed over the lawn of specific microorganism on MHA plates and then pure ginger extracts (20 $\mu l)$ were put on each disc separately. Soybean oil in combination with ginger was used in order compare the antimicrobial activity alone and with combination. Antibiotics clarithromycin discs (Oxoid, UK) easily available in the market were used as control over the lawn of microorganism on MHA plates as we used for ginger. All plates were incubated at $37 \mathrm{c}$ for 24 hours and the zones of inhibition (diameter in $\mathrm{mm}$ ) were measured over the agar by standard techniques.

\section{RESULTS}

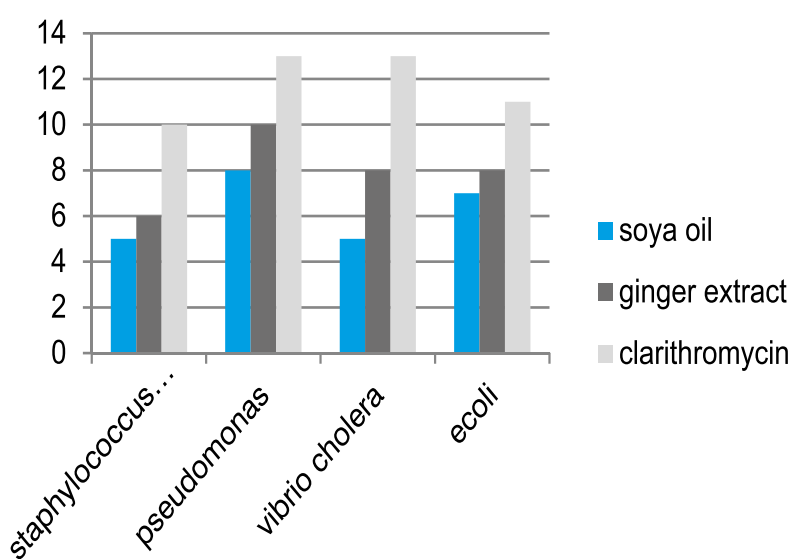

Figure-1. Graph shows antimicrobial activity 


\begin{tabular}{|l|c|c|c|}
\hline Organism & Ginger+soya oil & Ginger (alone) & Clarithromycin \\
\hline Staphylococcus aureus & $5 \mathrm{~mm}$ & $6 \mathrm{~mm}$ & $10 \mathrm{~mm}$ \\
\hline Pseudomonas & $8 \mathrm{~mm}$ & $10 \mathrm{~mm}$ & $13 \mathrm{~mm}$ \\
\hline Vibrio chlera & $5 \mathrm{~mm}$ & $8 \mathrm{~mm}$ & $13 \mathrm{~mm}$ \\
\hline E coli & $7 \mathrm{~mm}$ & $8 \mathrm{~mm}$ & $11 \mathrm{~mm}$ \\
\hline
\end{tabular}

Table-I. Zone of inhibition of different microorganism against clarithromycin, ginger and soya oil

It is shown from the above result that Staphylococcus Aureus Pseudomonas, Vibrio, Ecoli all having zone of inhibition against ginger after conventional antibiotic zone of inhibition. Among all organisms pseudomonas show maximum zone of inhibition against ginger.

\section{DISCUSSION}

Due to ever increasing cost and side effect of commonly used antibiotics researchers are now looking toward developing new antimicrobial agent those play role in eradicating pathogenic bacteria effectively. Also there is a problem of developing resistance against these antibiotic due to inadequate use of these drugs so looking into this scenario we are looking forward to explore natural product for their antimicrobial activity to save the human against these pathogenic bacteria. ${ }^{12,13}$

In this study we are using ginger as well as soya oil as antimicrobial agent against common human pathogen who have a ability to produce biofilm if not eradicated in initial stage and provide safe home for other microorganisms. We used ginger as individual as well as in combination of soybean oil. It is observed from the above result that although conventional antibiotic shown maximum zone of inhibition but after that disc which was soak with ginger having effective zone of inhibition. All of these results shows that ginger have some antimicrobial activity as shown in previous studies ${ }^{14,15,16}$ which is more effective than in combination soya oil because its zone of inhibition is more when used alone as compare to when in combination of soya oil as shown in Figure-1. Also it is observed that antimicrobial activity of ginger against pseudomonas is most effective as compared to other tested microorganism. And as the pseudomonas is very difficult to treat so it can be used as adjuvant drug with other antimicrobial drugs that is available. As shown in previous studies ${ }^{17,18,19,20}$ effectiveness of ginger is not as effective as conventional antibiotics but due to so many advantages that ginger have over antibiotic it seems to be an effective alternative choice against above organisms. Also resistance problem against organism also persist against these antimicrobial drugs.

To overcome this alarming problem, the discovery of alternative compounds against common pathogenic bacteria is a matter of urgency. Mostly natural compound extracts either in water or in organic solvents have biologically active compounds, which can be used in the synthesis of potent drugs or used as adjuvant drug with conventional antimicrobial therapies. Thus natural compounds which also be the part of our food ingredients and help in digesting food can also provide protection against certain pathogenic bacteria that is present in an environment.

\section{CONCLUSION}

The results of this research demonstrated the usefulness of ginger in treating bacterial infections causes by above mention microorganism and utilization of it is associated with health benefits. Ginger is readily available and according to increased tendency in the use of herbal and natural product medicine, especially for people who have no desire to use chemical drugs with some adverse effects use of ginger with very low undesirable effects is very useful in controlling infections. Also it may be added as supplemented antimicrobial drug with conventional drug therapies. Furthermore, we suggest doing more studies with larger number of patients concerning the efficacy and safety of different doses of ginger and with other natural product in combination so we would be able to develop some new and more effective individual or adjuvant antimicrobial 
agent.

Copyright(C 29 Sep, 2016.

\section{REFERENCES}

1. M. S. Baliga, R. Haniadka, M. M. Pereira et al., "Update on the chemo preventive effects of ginger and its phytochemicals," Critical Reviews in Food Science and Nutrition, vol. 51, no. 6, pp. 499-523, 2011. View at Publisher.

2. S. Chrubasik, M. H. Pittler, and B. D. Roufogalis, "Zingiberisrhizoma: a comprehensive review on the ginger effect and efficacy profiles," Phytomedicine, vol. 12, no. 9, pp. 684-701, 2005.

3. M. S. Butt and M. T. Sultan, "Ginger and its health claims: molecular aspects," Critical Reviews in Food Science and Nutrition, vol. 51, no. 5, pp. 383-393, 2011.

4. Savora D plant-denved antimicrobial compounds alternative to antibiotics. Future microbial 2012.

5. Durairaj S, Srinivasan S, Lakshmanaperumalsamy $P$ (2009). In vitro antibacterial Activity and Stability of Garlic Extract at different $\mathbf{p H}$ and Temperature. Elect. J. Biol. 5(1):5-10.

6. Ranjan S, Dasgupta N, Saha P, Rakshit M, Ramalingam C (2012). Comparative study of antibacterial activity of garlic and cinnamon atdifferent temperature and its application on preservation of fish. Adv.Appl. Sci. Res. 3(1):495-501.

7. J. EthnAli BH, Blunden G, Tanira MO and Nemmar A. (2008). Some phytochemical, pharmacological and toxicological properties of ginger (Zingiberofficinale Roscoe): Are view of recent research. Food Chem. Toxicol., 46(2): 409-420.

8. Lestari ES. Antimicrobial resistance among Staphylococcus aureus and Escherichia coli isolates in the Indonesian population inside and outside hospitals. 14th European Congress of Clinical Microbiology and Infectious Diseases. 2004. Prague / Czech Republic, May 1-4.

9. Chambers HF, Deleo FR. Waves of resistance: Staphylococcus aureus in the antibiotic era. Nat Rev Microbiol. 2009; 7(9):629-641.

10. Owlia P, Saderi H, Rasooli I, Sefidkon F. Antimicrobial characteristics of some herbal Oils on Pseudomonas aeruginosa with special reference to their chemical compositions. Indian J Pharmacol Res. 2009; 8(2):107114.
11. Oussalah, M.; Caillet, S.; Saucier, L. and Lacroix, M. (2007). Inhibitory effects of selected plant essential oils on the growth of fourpathogenic bacteria: E. coli 0157: H7, Salmonella typhimurium, Staphylococcus aureus and Listeria monocytogenes. Food Control, 18: 414-420.

12. Kim, E. and J. Min, T. Kim, S. Lee, H. Yang, S. Han, Y. Kim, Y. Kwon. "[6]-Gingerol, a Pungent Ingredient of Ginger, Inhibits Angiogenesis In Vitro and In Vivo." Biochemical and Biophysical Research Communications, 2005, vol. 335, pp. 300-308.

13. Hoffman, T. (2007). Antimicrobial activity of some medicinal plants from India. Hawaii Med. J., 66: 326327.

14. Chen IN, Chang CC, Ng CC, Wang CY, Shyu YT and Chang TL. (2008). Antioxidant and Antimicrobial Activity of Zingiberaceous Plants in Taiwan. Plants Foods Hum. Nutr. 63:15-20.opharmacol. 100(1-2):8084.

15. Malu, S. P.; Obochi, G. O.; Tawo, E. N. and Nyong, B. E. (2009). Antibacterial activity and medical properties of ginger (zingiberofficinale). global $\mathrm{J}$. of pure and applied sciences vol. 15 No.3:65-368.

16. Ali, B.H; Blunden, G.; Tanira, M.O. and Nemmar, A. (2008). Somephytochemical, pharmacological and toxicological properties ofginger (Zingiberofficinale Roscoe): a review of recent research. FoodChemToxicol.46 (2):409-20.

17. Onyeagba RA, Ugbogu OC, Okeke CU and Iroakasi O. (2004). Studies on the antimicrobial effects of garlic (Allium sativum Linn), ginger (Zingiberofficinale Roscoe) and lime (Citrus aurantifolia Linn). African Journal ofBiotechnology, 3 (10):552-554.

18. Demin G, Yingying, Z (2010) Comparative antibacterial activities of crude polysaccharides and flavonoids from Zingiberofficinale and their extraction. American Journal of Tropical Medicine 5: 235-238.

19. Sasidharan I, NirmalaMenon A (2010) Comparative Chemical Composition and Antimicrobial Activity Fresh \& Dry Ginger Oils (ZigiberOfficinale Roscoe). International Journal of Current Pharmaceutical Research 2: 40-43.

20. Sebiomo A, Awofodu AD, Awosanya AO, Awotona FE, Ajayi AJ (2011) Comparative studies of antibacterial effect of some antibiotics and ginger (Zingiberofficinale) on two pathogenic bacteria. Journal of Microbiology and Antimicrobials 3: 18-22. 


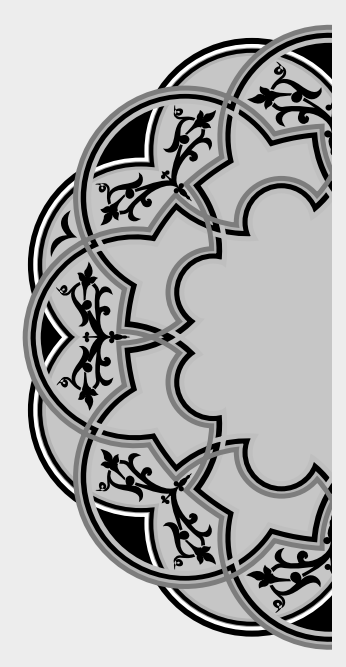

\section{“We can't help everyone, but everyone can help someone."}

\section{Unknown}

\section{AUTHORSHIP AND CONTRIBUTION DECLARATION}

\begin{tabular}{|c|c|c|c|}
\hline Sr. \# & Author-s Full Name & Contribution to the paper & Author $=s$ Signature \\
\hline 1 & Dr. Naveed Faraz & $\begin{array}{l}\text { Concept, Manuscript, } \\
\text { Writing, Lab work }\end{array}$ & \\
\hline $\begin{array}{l}2 \\
3\end{array}$ & $\begin{array}{l}\text { Dr. Shaista Khurram } \\
\text { Dr. Sehrish }\end{array}$ & $\begin{array}{l}\text { Data, Analysis, Results } \\
\text { Discussion }\end{array}$ & \\
\hline
\end{tabular}

